\title{
THE ROLE OF FOREIGN ECONOMIC ACTIVITIES IN RURAL DEVELOPMENT
}

\author{
Oleksandr Galych, Elena Sirenko, Julia Vitko \\ Poltava State Agrarian Academy, Ukraine
}

\begin{abstract}
The economic contents of foreign economic activities, the necessity and importance of their implementation for economic development have been investigated and proved in the article. The features, main factors of influence, and possibilities of intensifying foreign economic activities of rural areas have been defined. The conclusion about the close interrelation between rural development and agriculture has been made. The basic tendencies and problems of foreign economic activities implementation in the agricultural sector have been analyzed. The directions and priorities of rural development by foreign economic activities implementation have been defined and proposed.
\end{abstract}

Keywords: rural areas, foreign economic activities, agriculture, agricultural sector

DOI: 10.17512/znpcz.2016.1.13

\section{Problem statement}

Under the existing conditions of economic crisis and military confrontation, agriculture remains the main stabilizer of economic development and functions as one of the main budget revenue generating sectors of the national economy. At the same time, there are negative trends in rural development, manifested in the decrease of living standards in rural areas, the increase of labor migration to the cities, the existence of a number of demographic and social problems, the reduction of agricultural land area, economic stagnation, and the environmental degradation in rural areas.

The solution of the existing problems requires searching for alternative ways of overcoming the crisis, including the development of rural areas by internsifying foreign economic activities which can be one of the efficient mechanisms for the human potential development and create a highly competitive agricultural sector in the domestic and foreign markets.

\section{The review of the recent research and publications}

A wide range of publications is devoted to the problems of rural development in Ukraine. The research results have been widely covered in the works by Ukrainian scholars who pay special attention to different aspects of rural development to ensure a rapid economic growth in Ukraine. A large number of researches are devoted to the international aspect of rural development. Such scholars as V. Borshchevsky (Borshchevsky 2012), M. Gylka (Glyka 2015, pp. 124-129), 
A. Klyuchnik, I. Irtyshcheva, O. Shebanina (Klyuchnik, Irtyshcheva, Shebanina, 2013, p. 336) focus on rural development in the system of European integration priorities of Ukraine and in the context of international cooperation, M. Stegney (Stegny 2013, pp. 125-133), O. Nepochatenko (Nepochatenko 2012, pp. 149-153), T. Gogol (Gogol 2012.) lay stress on the problem of sustainable rural development as a part of state regulation of the Ukrainian economy taking into account the experience of the European Union countries (Kalinichenko, Minkova, Sakalo, 2015, pp. 10-14). Despite the impressive number of publications devoted to the international aspect of rural development, it should be noted that they have not sufficiently studied the question of the role of foreign economic activities to provide the effective functioning of rural areas.

\section{The formulation of the tasks}

The main goal of this research is to determine the role of foreign economic activities in rural development and especially their implementation at present.

\section{The results}

The economic aspect of foreign economic activities (FEA) means that they serve as a way for the integration of every country into the system of the world economy, and hence, into the processes of international division of labor and international cooperation, which is particularly important because of the growing trend towards globalization (the regional and global aspects of FEA) (Shkurupiy, Goncharenko, Artemenko et al. 2012, p. 6) and it is an important and powerful factor of economic growth and development of every country (the national aspect of FEA). Foreign economic activities are a multidimensional integrated system of economic relations between economic subjects of different countries. Covering all the aspects of economic life, they involve such two main subsystems of activities as foreign trade and international production and investment, each of which covers some definite aspects of economic life or its elements (Kozak, Logvinova., Rzhepishevskiy, 2010, p. 6).

The expediency of trade foreign economic activities can be explained as follows:

- the unevenness of developing separate branches stimulates the export of products from the most developed areas and the import of products the production of which in the country is undeveloped or more expensive compared to those bought abroad;

- the striving for production unlimited expansion, that in domestic market is limited by the insufficient demand of the population;

- the purpose of profit maximization by using imported resources with relatively better quality characteristics.

International production and investment activities are related to the implementation of common projects and programs as a result of interaction and rationalization in a single process of uniting material, financial, human, and intellectual resources and factors. This level represents a general trend of social and dynamic process making a defining influence on economic development. 
Foreign economic activities activate some aspects of the national economy: they satisfy the existing needs in raw materials, technologies; accelerate and stimulate the effective use of internal resources; provide the comparability of costs on the national and international level; create additional working places; optimize the increase of production. The formation of additional demand helps to overcome the narrowness of domestic market, to expand production by taking the advantages of the scale economy effect, to improve technical and economic level, and the efficiency of production. At the same time, intensive development of the world market is characterized by high competition forcing domestic producers continuously to increase their competitiveness, improve product quality and pay more attention to the problem of compliance with the marketing principles and methods.

Foreign economic activities optimize the economic development, on the one hand, through the opportunities of existing benefits' implementation, and on the other hand, by creating new ones. The multifaceted indirect effect is connected with the creation of numerous enterprises serving the external sector (related and auxiliary productions, suppliers, associate contractors) and helping to overcome inertia which is another component of economic growth (Kozak, Sporek, Molendowski, Gribincea, Lebedeva., Shengelia, Logvinova., Kozak, Prytula, Osipov, Aliabieva, Kochevoy 2015, p. 46). The creation of the subjects of foreign economic activities is the essential direction of improving the existing potential for the implementation of rural development.

The rural areas are characterized as the source of a large number of material and non-material values, which include manufactured products, a large resource base for many sectors of the economy, natural resources, recreational facilities, and other resources that ensure the vital activities for both the local population, and the population in other areas (Klyuchnik, Irtyshcheva, Shebanina 2013, p. 11).

At the same time, the main factors affecting the development of foreign economic activities in rural areas are the existing production relations; the system of management; the degree of economic freedom and exposure of foreign markets; the level of competition and the international competitiveness of domestic products; the level of risk, the experience and scale of foreign economic activities; the level of production costs; technical level and the state of basic assets; the availability of natural, financial, labor, and other resources; geographical conditions; the development of infrastructure, and so on.

From the standpoint of development opportunities of foreign economic activities, the rural areas of Ukraine have a significant production potential. The availability of land resources helps them play a leading role in the factors of production, which creates a kind of foundation for the economic rural development. The main product is created in the agricultural sector, where the majority of rural population is occupied, because of the lack of alternative for employment and the sources of income in these areas. However, a significant proportion of the economically active population is involved in agricultural production with the purpose of satisfying their own needs by participating in market relations only through the selling of surpluses in local markets. 
The current orientation of agricultural production for life self-sufficiency of the rural population reduces the functional use of rural areas and requires finding ways to develop the existing productive capacity that far exceeds the domestic demand. Under the existing conditions the activation of foreign economic activities in rural areas through selling agricultural products in the international market is seen as one of the ways to ensure their progressive development and create the conditions for the successful development of other industries.

Small-scale commodity production and land scattering are characteristic of the rural areas which, in case of foreign economic activities, negatively affect the quality and competitiveness of domestic products in the world market. Currently, the similar behavior in performing export operations is proper to Ukrainian agricultural manufacturing enterprises that conduct foreign economic activities, and it is caused by the size of the company, the experience in foreign trade, and the production of identical agricultural products (Cherevko 2012, p. 12). One of the ways to solve this problem could be the development of rental relations between farms and large producers, and promoting the creation of integration associations (clusters, alliances, associations, holdings, etc.) in the field of cooperation, and the relationship of agricultural manufactures with banks. Export potential of large-scale production enterprises that concentrate their activities on processing of products, combine the manufacturing of agricultural products with non-agricultural activities, and use modern marketing strategies (including international) and methods of management, is considerably higher compared to small-scale production farms.

From the standpoint of the close relationship of rural development with agriculture, it is advisable to pay attention to the main trends and problems of intensifying foreign economic activities in the agricultural sector.

The extensive nature of both agriculture and the development of most sectors of the rural economy are observed in Ukraine, like in many developing countries. The agricultural output is far behind the neighboring countries with similar geographical and climatic conditions (Borshchevsky 2012). Taking into account a large number of employed people in agriculture and the essential areas of farmland, the agricultural output and yield capacity are relatively low. All this results in the loss of economic benefits from potential products' selling in the domestic and foreign markets threatening the economic rural development.

Insufficient production output is the primary obstacle to the agricultural export development. However, not only quantitative but also qualitative aspect of production is important for the rural development. Deterioration of basic assets and the use of outdated technologies by agricultural producers lead to low economic efficiency of agricultural enterprises. Most of agricultural enterprises are not able to carry out technical and technological renovation of production because of lack of funds, high prices for material resources, imperfection of credit and financial system, which in its turn leads to inability to produce high-quality products which are competitive in the international market and correspond to international standards of quality and safety. The problem of product quality adaptation to the European Union requirements becomes particularly topical, considering the chosen Western European course of development, which requires a careful study of the future possibilities of the development of foreign economic activities. 
The dynamics of agricultural and processed products export in Ukraine reflects the general trends of economic development of Ukraine. Considering the economic and political situation in the country, the data for the period from 2010 do not include the temporarily occupied territory of the Autonomous Republic of Crimea and Sevastopol city (Figure 1).

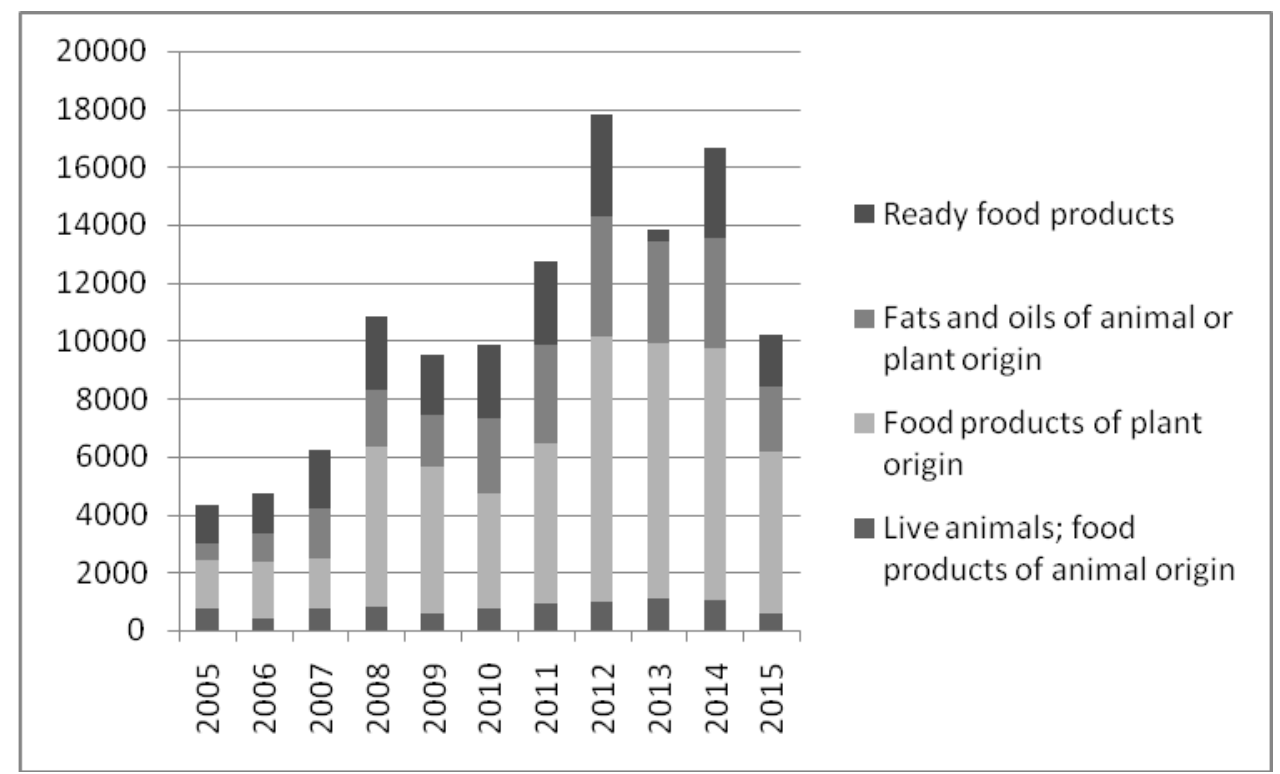

Figure 1. The dynamics and structure of agricultural and processed products export in Ukraine, ths. USD

Source: http://www.ukrstat.gov.ua Data of 2010-2014 is pointed without including temporarily occupied territory of the Autonomous Republic of Crimea, Sevastopol city. Data of 2015 is pointed for 9 months without including the temporarily occupied territory of the Autonomous Republic of Crimea and Sevastopol city and the zone of the antiterrorist operation.

The largest share of agricultural products export during the analyzed period belongs to plant growing products which for 9 months of 2015 amounted to $19,8 \%$ of total exports of the country (primarily, these are grain crops, seeds, and oil plant seeds). The export of fats and oils of animal and plant origin was smaller $(8,0 \%)$, ready food products' export $(6,3 \%)$ together with live animals and animal products export $(2,1 \%)$ was equal to $36,2 \%$ of the total exports of the country, or $10,2 \mathrm{bln}$. USD.

The dynamics of food and agricultural products' import is characterized by the decline in recent years, which can be explained by the decrease of purchasing power of the Ukrainian population (Figure 2). The factor of reducing industrial potential of enterprises that operate using imported raw materials is secondary in this case. In the structure of agricultural import in 2015 the largest share belongs to food products' import $(4,1 \%$ of total imports), vegetable products $(3,1 \%)$, live 
animals and animal products $(1,4 \%)$, and fats and oils of animal and plant origin $(0,5 \%)$. Overall, in 2015 the agricultural products were imported in the amount of 2,5 bln. USD, which constitute $9,1 \%$ of the total national imports.

The negative phenomenon is that products with a low degree of processing and low added value dominate in the domestic agricultural exports. It is a significant threat for the rural development. The available own raw materials' potential enables the manufacturers of agricultural products' sector to export unprocessed produce receiving sufficient profits without investing additional resources to the increase of production capacities for processing. It has led to the increased raw materials' orientation of production.

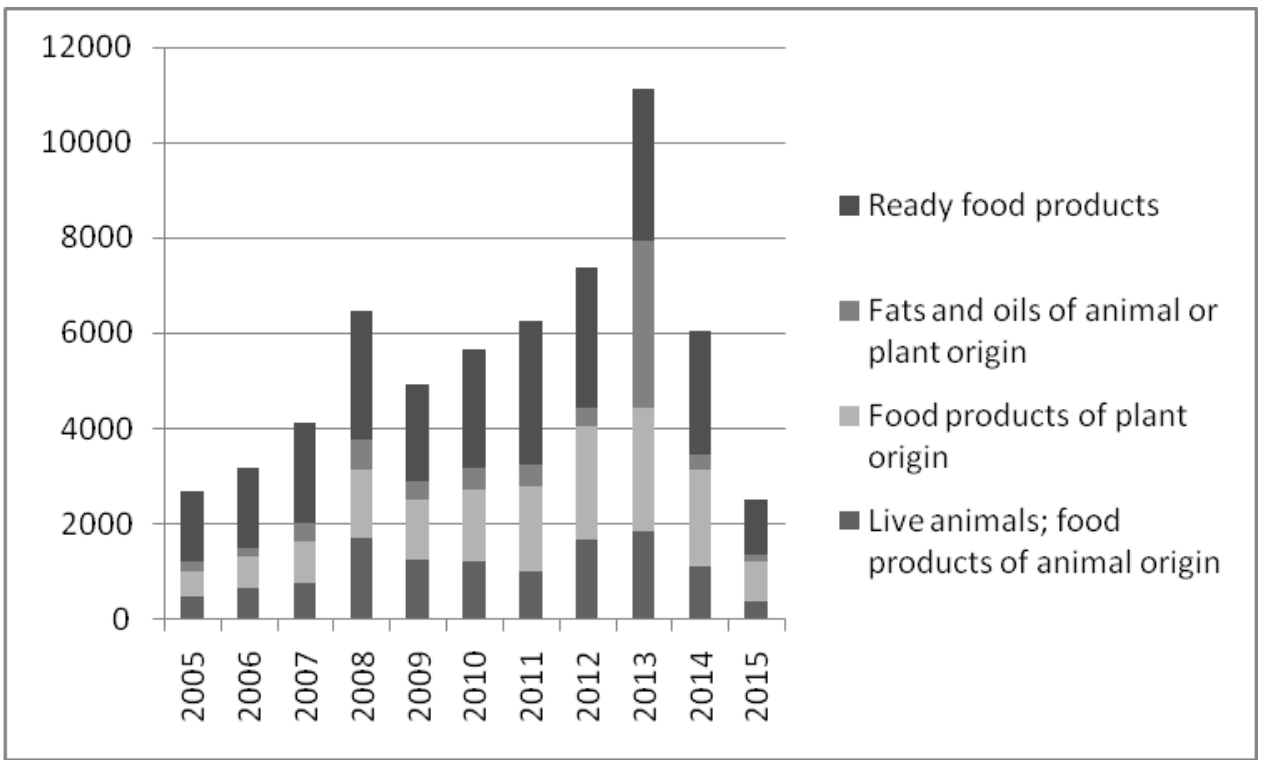

Figure 2. The dynamics and structure of agricultural and processed products import in Ukraine, ths. USD

Source: http://www.ukrstat.gov.ua Data of 2010-2014 is pointed without including temporarily occupied territory of the Autonomous Republic of Crimea, Sevastopol city. Data of 2015 is pointed for 9 months without including the temporarily occupied territory of the Autonomous Republic of Crimea and Sevastopol city and the zone of the antiterrorist operation.

The situation in import revenues is opposite: a large share of agricultural and food products' import belongs to finished products. This also confirms the orientation of agricultural enterprises to the production of raw materials for both internal and external markets. The dominance of the exported agricultural products with a low degree of processing does not conform to the generally accepted foreign trade policies and increases the dependence on foreign technologies and capital. This situation illustrates the problem of raw material orientation of domestic production and exports, and the need of reorientation to the production of finished products which could be potentially exported. 
At the same time, we must note that the increase of world prices on manufactured and exported products has a total positive impact on exports and increases profitability. However, on the other hand, in the context of globalization price rising in the world market provokes price rising in the domestic market. Further liberalization of foreign trade creates a threat of internal agricultural market dependence on the world market fluctuations, which will increase uncertainty concerning production costs and natural indicators.

The performed analysis demonstrates the critical problems in the development of foreign economic activities in the agrarian sector. Taking into account the above mentioned risks it is necessary to improve the competitiveness of agricultural enterprises, search for reserves and instruments of foreign economic growth of rural areas. The priority directions of rural development by foreign economic activities' implementation at the present stage can be:

1. The transition from international specialization of agricultural raw materials' export to the manufacturing of high marginal products. The analysis of production structure in developed countries shows that the main factor of successful economic development has become the development of production industries and areas, where the main part of added value is formed. For the enterprises, the benefit of producing goods with high added value means receiving higher profits, the opportunity to enter new markets including those in developed countries, the reducing spending on products' transportation and storage. In general, for rural areas it leads to income growth, productivity improving and raising wages, infrastructure developing, new opportunities for attracting investments, reducing the dependence on the price environment. Perspective model of development could be, on the one hand, the unification of high quality arable farming and plant growing development with the transition from primary processing to raw material processing. And on the other hand, it could be the creation of opportunities for the development of livestock farming and non-agricultural kinds of production.

2. The increase of technical and technological level of production by capacities' re-equipment. Technological modernization and the creation of the mechanism of implementing innovations into production will allow to increase the efficiency of agricultural and other enterprises operating in rural areas, through the production of high-quality and competitive products. This will promote the formation of science-intensive, resource-saving, ecologically safe productions that will be able to satisfy the needs of domestic and foreign markets. Special attention here is payed to increasing the innovation level of agricultural production as the basis for economic modernization of rural areas.

3. The shift of accent to the quality and safety of products manufactured in rural areas, their adaptation to international requirements and standards. Together with innovations and update of products, comprehensive quality management programs for ensuring competitiveness should be implemented at the enterprises. The adaptation to international standards will open up additional opportunities for domestic exporters, create favourable conditions for the promotion of Ukrainian goods into the world market, and increase the efficiency of business entities' functioning in rural areas. 
4. The strengthening of export positions in the world market requires solving problems of small-scale production in rural areas. This requires the creation of integration associations (clusters, alliances, associations, holdings, etc.), cooperation of producers with banks, introduction of the most effective forms of cooperation with foreign companies, which will give the opportunity to strengthen the positions in the traditional markets and to develop new ones.

\section{Conclusions}

This research indicates at the existing critical problems of rural development that require searching for alternative ways of their solving, one of which may be the development of foreign economic activities. As a result, the priority directions of the implementation of foreign economic activities have been defined. They are primarily oriented at the stimulation of improving the effectiveness and competitiveness of domestic agricultural and other enterprises operating in rural areas. The implementation of the above mentioned measures towards solving the existing problems will enable to create favorable conditions for the further development of the rural areas' potential, to accelerate the modernization of the Ukrainian village, to improve the social and economic situation in rural areas. Further research of this problem may concern the evaluation of the influence of each measure on rural development.

\section{References}

1. Borshchevsky V.V., Rural development in the system of European integration priorities of Ukraine: monograph, NAS of Ukraine. Institute of Regional Studies. - Lviv, 2012, p. 216.

2. Glyka M.D., Rural development of Ukraine in the context of European integration, global and national economic problems. - Issue. 4. - Mykolayiv, 2015, pp. 124-129.

3. Klyuchnik A.V., Irtyshcheva I.A., Shebanina O.V., Rural development in the context of international cooperation: monograph. - Mykolayiv: Design and polygraphy, 2013, p.336.

4. Stegny M.I., Current trends of sustainable rural development: European experience and Ukrainian realities. // Current problems of Economy: Economic Science magazine. - № 3. 2013, pp. 125-133.

5. Nepochatenko O.O., State policy in the rural development sphere, domestic realities and European experience. // Scholarly works of Poltava State Agrarian Academy. Series: Economics. - Vol. 1 (4). - Issue 3. - 2012, pp. 149-153.

6. Gogol T.V., Formation of the Common Agricultural Policy of the European Union and the Rural Development Regulation // State Administration: Theory and Practice: Electronic scientific specialized magazine. - № 1. - 2012.

7. Kalinichenko A., Minkova O., Sakalo V., Main directions in development of organic industry in Ukraine and experience of innovation implementation: a comprehensive analysis. // J. Technology audit and production reserves, Nr 5/3(25), 2015, pp. 10-14. DOI: $10.15587 / 2312-8372.2015 .50677$

8. Shkurupiy O.V., Goncharenko V.V., Artemenko I.A. et al., Foreign economic activity of enterprises: textbook edited by O.V. Shkurupiy. - Kyiv, Center of educational literature, 2012 , p. 6.

9. Kozak J.G., Logvinova N.S., Rzhepishevskiy K.I., Foreign economic activity of enterprises: credit modular course: Tutorial. - 3rd ed., Revised. and ext. - Kyiv, Center of educational literature, 2010, p. 6. 
10. Kozak J.G., Sporek TV, Molendowski E., Gribincea A., Lebedeva S.N., Shengelia T., Logvinova N.S., Kozak A., Prytula N.V., Osipov V.M., Aliabieva D., Kochevoy M.M., International trade: textbook. - 5th Edition, revised. and ext. - Kyiv-Katowice-Krakow, Center of educational literature, 2015, p. 46.

11. Klyuchnik A.V., Irtyshcheva I.A., Shebanina O.V., Rural development in the context of international cooperation: monograph. - Mykolayiv: Design and polygraphy, 2013, p. 11.

12. Cherevko V.D. Foreign economic activity of agricultural enterprises in the conditions of globalization: the dissertation... candidate. econ. science, spec.: 08.00 .04 - economy and management of enterprises (by economic activities), Ministry of Agricultural Policy and Food of Ukraine, Kharkiv National Technical University of Agriculture. - Kharkiv, 2012, p. 12.

13. http://www.ukrstat.gov.ua. Data of 2010-2014 is pointed without including temporarily occupied territory of the Autonomous Republic of Crimea, Sevastopol city. Data of 2015 is pointed for 9 months without including the temporarily occupied territory of the Autonomous Republic of Crimea and Sevastopol city and the zone of the antiterrorist operation.

\section{ROLA ZAGRANICZNYCH DZIAŁAŃ GOSPODARCZYCH W ROZWOJU OBSZARÓW WIEJSKICH}

Streszczenie. W opracowaniu zbadano i wykazano przedmiot ekonomiczny zagranicznych działań gospodarczych oraz konieczność i znaczenie ich wdrożenia dla rozwoju gospodarczego. Określono cechy, główne czynniki wpływu oraz możliwości intensyfikacji zagranicznych działań gospodarczych obszarów wiejskich. Wysunięto wniosek dotyczący ścisłego wzajemnego powiązania między rozwojem obszarów wiejskich a rolnictwem. Dokonano analizy podstawowych tendencji i problemów dotyczących realizacji zagranicznych działań gospodarczych w sektorze rolniczym. Określono i zaproponowano kierunki i priorytety rozwoju obszarów wiejskich poprzez realizację zagranicznych działań gospodarczych.

Słowa kluczowe: obszary wiejskie, zagraniczne działania gospodarcze, rolnictwo, sektor rolniczy 